\title{
Coding of Phenotypic Data Descriptive of Selected Groups of Fungi for Entry into Computers
}

\author{
C. M. PHILPOT, ${ }^{1}$ M. I. KRICHEVSKY, ${ }^{2}$ AND M. ROGOSA ${ }^{2}$ \\ Public Health Laboratory, St. Lukes Hospital, Guildford GUI 3NT, United Kingdom, ${ }^{1}$ and Microbial \\ Systematics Section, National Institute of Dental Research, Bethesda, Maryland $20205^{2}$
}

Based upon an existing open-ended method for encoding data on bacterial strains, a complementary list of features applicable to fungal strains is described herein. Thus, information on fungal strains can be stored, retrieved easily, and processed for various mathematical and taxonomic analyses using computer technology.

The dynamically increasing size, sophistication, and complexity of modern microbiological studies have produced a large body of phenotypic data on many strains of microorganisms. The information in such data bases often requires the use of computer techniques to facilitate its management, analysis, and comprehension. Indeed, some taxonomic, ecological, and epidemiological studies are not convenient and may not be feasible without computer aid. A uniform coding method for entering phenotypic data into computers is desirable and even necessary to avoid redundancies, errors, and confusion in the management of increasingly large volumes of data within and between laboratories. A method applicable to bacteria was first published by Rogosa et al. (10) in 1971. The coded items used in this system, referred to as the RKC Code, have now been expanded to about 10,000 , and they include contributions by many individuals who suggested a large number of new descriptive features. This expanded list of bacterial features has been maintained over the years by the original authors (10). Benedict (1) has described the flexibility, specificity, expandability, and user orientation built into the RKC Code. Computer programs using the RKC Code integrated into a comprehensive Microbial Information System have been discussed by Krichevsky (8).

Computer analysis techniques for fungi have been applied to taxonomic studies on the yeast genera Candida and Torulopsis (2). They have only seldom been used for other fungi (4-7), although there is no valid reason for this.

Historically, fungi have been classified by cultural and morphological features and their mode of reproduction. Biochemical and physiological features have not been major factors in fungal taxonomic schemes.

Mycologists tend to weight certain characteristics considered to be important in delineating taxonomic groups. Usually, these differences are not expressed in the simplified language most useful for computer coding, i.e., as unweighted binary, or yes-no, information.

To avoid dependence on variable features which may be significantly influenced by environmental conditions, Philpot (9) tested the ability of 147 isolates representing 22 species of dermatophytes to grow on or assimilate a variety of single carbohydrate and nitrogen substrates. Such physiological data lend themselves to treatment by the techniques of numerical taxonomy.

In an unpublished pilot study, a list of physiological features was prepared by Philpot from the dermatophyte data. Additional data on cultural and microscopic morphological features of the same isolates were also included. Because there appeared to be improved differentiation of the dermatophytes as the feature list was enlarged, it seemed profitable to extend the original mycological feature list to include data on certain medically important species of fungi from the genera Aspergillus, Phialophora, Exophiala, Wangiella, and Cladosporium.

The expansion of the RKC coding system to embrace additional features applicable to a variety of fungi is the subject of this communication.

\section{MATERIALS AND METHODS}

The general system of coding in Table 1 is the RKC Code as described by Rogosa et al. (10). Each feature item has a six-digit code number which is unique and can be used for only one descriptive feature. In the master RKC Code, the feature items are arranged in sections. For example, the code numbers in Section 3 on Individual Cell Morphology would all begin as 003 . . . , and the numbers in Section 37 on the Nucleus would be written as 037001 to 037999 . Table 1 was constructed so that this was the general rule, but logical and scientific purposes were sometimes better served by including some code numbers from diverse sections. For computer purposes, the order of code numbers is unimportant.

Code sheets on which features may be coded were developed and illustrated, and their employment was 
TABLE 1. List of features descriptive of selected groups of fungi

\section{SPECIFIC STRAIN INFORMATION}

002001: What is your laboratory strain number? Use any combination of 10 numbers and/or letters (CODE SHEET-I, Columns 1-10 and Columns 1-10 on all subsequent code sheets).

002002: Is the strain a mutant of another strain which mutated in your collection (for other known mutants as well as the general history of each strain, see 02013, below)? (CODE SHEET-I, Column 11)

002003: If the strain mutated in your collection, what is the parent strain number? (CODE SHEET-I, Columns 12-21)

002004: What is the specific epithet? (CODE SHEET-I, Columns 22-46)

002005 : What is the authority for the specific epithet, i.e.,Author's name, Journal, Year)? (CODE SHEET-I, Columns 47-70)

002007: What is the G.C. content of the strain DNA, in moles \% (to the nearest whole number)? (CODE SHEET-II, Columns 12-13)

002008: Which culture collection is the strain deposited in? Use any combination of 6 letters or, if known, use the World Directory of Culture Collections Number. (CODE SHEET-II, Columns 14-19)

002009: What month and year was the strain deposited in the culture collection? Use 01 for January through 12 for December (CODE SHEET-II, Columns 20-21) and the last two digits of the year. (CODE SHEET-II, Columns 22-23)

002010: Is the geographic place of isolation known? (CODE SHEET-II, Column 24) If known, please supply, as much as possible, the following information on a separate sheet of paper; (a) name of place (b) latitude and longitude, both in degrees, minutes, seconds (c) altitude in meters, + or - from sea level.

002011: Date of isolation? Use 01 for January through 12 for December (CODE SHEET-II, Columns 25-26) and the last two digits of the year. (CODE SHEET-II, Columns 27-28)

002012 : What was the specific source of isolation, i.e., kind of water, soil, etc., species and organ of plant, animal, etc. (give specific type). (CODE SHEET-II, Column 29-70)

002013: Is the history of the culture known? If it is, indicate by answer on CODE SHEET-III (see DIRECTIONS for the method of using cODE SHEET III). If known, please supply, as much as possible, the following information on a separate sheet of paper; (a) origin of the culture (b) name and address of depositor of the culture (c) previous designations of the culture (d) names of the culture collections where the culture was previously held (e) applications of the culture.

002017: Has this strain been used in a numerical taxanomy study?

002018 : Has this strain been examined by electron microscopy?

002019 : Was the electron microscopy technique of shadow casting used?

002020: Was the electron microscopy technique of negative staining used?

002021 : Was the electron microscopy technique of thin sectioning used?

002022 : Was the electron microscopy technique of freeze etching used?

002023 : Was the scanning electron microscope used?

INDIVIDUAL CELL MORPHOLOGY AND ARRANGEMENT, SIZE, AND MODE OF CELL DIVISION

003001: Cells are spherical.

003002 : Cells are cuboid or angular.

003003 : Cells are bean-shaped (kidney-shaped).

003004: Cells are ellipsoidal.

003005 : Cells are pear-shaped. 
TABLE 1-Continued

Individual Cell Morphology and Arrangement, Size, and Mode of Cell Division-Continued

003006 : Cells are disc-shaped.

003007 : Cells are triangular.

003008 : Cells are rod-shaped.

003025 : Cells are dumbbell-shaped.

003027 : Cells are ogival.

003028 : Cells are apiculate.

003029 : Cells are horseshoe (i.e., "Un)-shaped.

003030: Cells curve into an almost complete circle.

003023 : Pleomorphic cells are characteristic.

015001 : Cells occur singly.

015002 : Cells occur in pairs.

015003: Cel1s arranged in angular fashion after division (snapping).

015004: Cells occur in chains.

015005 : Cells arranged in irregular aggregates.

004001: Longest axis of each cell is less than $0.5 \mathrm{micrometer.}$

004002 : Longest axis of each cell is 0.5 - 1 micrometer.

004003 : Longest axis of each cell is 1.1 - 2.0 micrometers.

004004: Longest axis of each cell is 2.1 - 3.0 micrometers.

004005 : Longest axis of each cell is $3.1-4.0$ micrometers.

004006 : Longest axis of each cell is 4.1 - 5.0 micrometers.

004007: Longest axis of each cell is 5.1 - 10 micrometers.

004008 : Longest axis of each cell is 11 - 15 micrometers.

004009: Longest axis of each cell is 16 - 100 micrometers.

004010: Longest axis of each cell is 101 - 160 micrometers.

004011 : Shortest axis of each cell is less than 0.5 micrometer.

004012 : Shortest axis of each cell is $0.5-1 \mathrm{micrometer.}$

004013 : Shortest axis of each cell is $1.1-2.0$ micrometers.

004014 : Shortest axis of edch cell is 2.1 - 3.0 micrometers.

004015 : Shortest axis of each cell is 3.1 - 4.0 micrometers.

004016 : Shortest axis of each cell is 4.1 - 5.0 micrometers.

004017: Shortest axis of each cell is 5.1 - 10 micrometers.

004018 : Shortest axis of each cell is 11 - 15 micrometers.

004019 : Shortest axis of each cell is 16 - 100 micrometers.

004020 : Shortest axis of each cell is $101-160$ micrometers.

014001: Individual cells divide transuersely (along the shortest axis) by binary fission.

014002: Individual cells divide longitudinally calong the longest axis) by binary fission.

014003: Cells reproduce by budding directly from mother cell.

014004: Daughter cells bud on tubular outgrowth from mother cells.

014008: Monopolar budding occurs cbuds occur only at one site on the mother cells.

014011: Bipolar budding occurs cbuds occur only at opposite ends of the mother celli).

011001: Capsule is present.

011002: Capsule is predominantly polysaccharide.

011003 : Capsule polysaccharide is antigenic.

011004: Capsule is predominantly polypeptide.

\section{NATURE OF THE CELL WALL}

023001: Cell wall present.

023002 : In electron micrographs of thin-sections of organisms the cell wall appears as a layer homogeneous in density, 100-800 angstroms thick, extracellular to the plasma membrane.

023072 : Cell wall contains polysaccharides.

023073: Cell wall polysaccharide is group-specific precipitinogen.

023074 : Cell wall polysaccharide is type-specific precipitinogen.

023076: Cell wall polysaccharide contains hexose residues. 
Nature of the Cell Wall-Continued

023077 : Cell wall polysaccharide contains hexosamine residues.

023078: Ceil wall polysaccharide contains pentose residues.

023079 : Cell wall polysaccharide contains uronic acid residues.

023080: Cell wall polysaccharide contains deoxysugar residues.

023123 : Cell wall polysaccharide contains 6-deoxyhexose residues.

023124: Cell wall polysaccharide contains rhamnose residues.

023125: Cell wall polysaccharide contains galactose residues to < $2 \%$ of the cell wall dry weight.

023126: Cell wall polysaccharide contains galactose residues to $>2 \%$ of the cell wall dry weight.

023127: Cell wall polysaccharide contains glucose residues to < $2 \%$ of the cell wall dry weight.

023128: Cell wall polysaccharide contains glucose residues to $>2 \%$ of the cell wall dry weight.

023129: Cell wall polysaccharide contains glucoseamine residues.

023430: Cell wall polysaccharide contains hexosamine residues other than glucoseamine.

023131: Cell wall polysaccharlde contains fucose residues.

023132 : Cell wall polysaccharide contains xylose residues.

023133 : Carbohydrate content of the cell wall is $>20 \%$.

023087: Lipid present in cell wall (particularly phospholipid).

023088 : Total lipid of cell wall< $3 \%$ dry weight.

023089 : Lipopolysaccharides present in cell wall.

023090: Lipopolysaccharide can be extracted as an endotoxic complex with protein.

023092: Polysacchoride of lipopolysaccharide contains heptose.

023093 : Polysaccharide of 1 ipopolysaccharide contains hexoses.

023102 : Cell wall contains waxes (glycolipids to $>5 \%$ of the dry weight).

023103: Cell wall contains lipoprotein.

023104 : Cell wall contains protein not associated with lipid.

023105 : Cell wall protein is antigenic.

023106: Cell wall protein shows type-specific antigenicity.

023107: Cell wall protein is associated with virulence.

023108 : Cell wall protein appears to have "structural" role.

023109 : Cell wall protein has enzymic activity.

HYPHAL BRANCHING, SEPTATION, AND DIFFERENTIATION

008336 : Mycelial growth occurs.

008662 : True mycelium is produced.

008663 : Pseudomycelium is produced.

008004 : Primary hyphae are produced.

008006: Primary growth is in the form of branched hyphae lying in the substrate (substratal).

008008: Secondary (aerial) hyphae are produced.

008009 : Branching hyphae have clavate ends.

008342 : Hyphae are septate.

008343 : Hyphae are simple-septate.

008344: Hyphae are nodose-septate (clamp connections present).

008345 : Clamp connections are single.

008346: Clamp connections are multiple.

008012 : Septa are produced at the origins of the branches in addition to any in the parent filament.

008013 : Septa are produced transuersely.

008014: Septa are produced transuersely and longitudinally.

008337 : Hyphae differentiate.

008338 : Hyphae have irregularly thickened walls (lumen diameter varles).

008339: Hyphae have scattered thick refractive areas on walls.

008340 : Hyphae have projections on external surfaces of walls.

008341 : Hyphae have resinous masses clinging to walls. 
TABLE 1-Continued

Hyphal Branching, Septation, and Differentiation-Continued

008348 : Hyphae have swellings (outside diameter.varies).

008349 : Hyphae have empty (non-staining) lumen.

008406: Spiral hyphae are produced.

008407: Pectinate (one side smooth, one side irregular) hyphae are produced.

008408: Favic (antler-like) hyphae are present.

008410: Proliferating organs are present.

008411: Hyphal branches are reflexive.

008413: Hyphae are straight.

008414: Hyphae are sinuous.

008415: Hyphae are contorted.

008416: Raquet hyphae are produced.

008417 : Rhizoids (root-like hyphae) are present.

008418: Rhizoids are found at nodes.

008419: Rhizoids are found at internodes.

008420: Stolons are present.

008015 : Hyphae fragment.

008016 : Primary hyphae fragment.

008017: Secondary hyphae fragment.

008018 : Fragmentation of hyphae at septa is complete.

008019: Fragmentation of hyphae at septa takes place only on terminal hyphae.

008020: Fragmentation results in exogenous arthrospores.

008363 : Chlamydospores are present.

008421: Chlamydospores are terminal.

008422: Chlamydospores are intercalary.

008423: Chlamydospores are sessile.

008424: Chlamydospores are stalked.

008425: Chlamydospores (gemmae) are spiny.

008426: Chlamydospores are pigmented.

008027 : Sclerotia are produced.

008427: Sclerotia are globose (i.e., round).

008428: Sclerotia are irregular.

008429: Sclerotia are ovate.

008430: Sclerotia are cylindrical.

008431: Sclerotia are tufted.

008432 : Sclerotia are pigmented.

008028: Coremia are produced.

008353 : Hyphae form cuticular cells (cells closely packed to form a pseudo-parenchyma).

008355 : Hyphae aggregate to form rhizomorphs.

008356: Hyphae form bulbils (knots).

008357 : Cystidia are present.

008358: Gloeocystidia are present.

008359: Setae are present.

008360 : Cystidia are present on primary hyphae (vegetative hyphae).

008361 : Cystidia are present in hymenium of fruiting areas.

008362 : Setae are present on primary hyphae (vegetative hyphae).

008367: Setae are present in hymenium of fruiting areas.

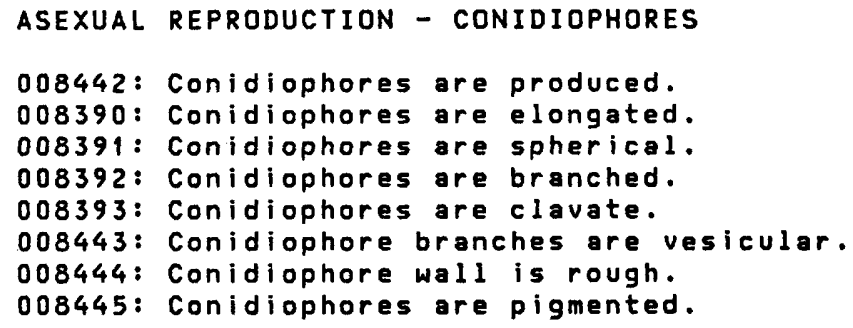




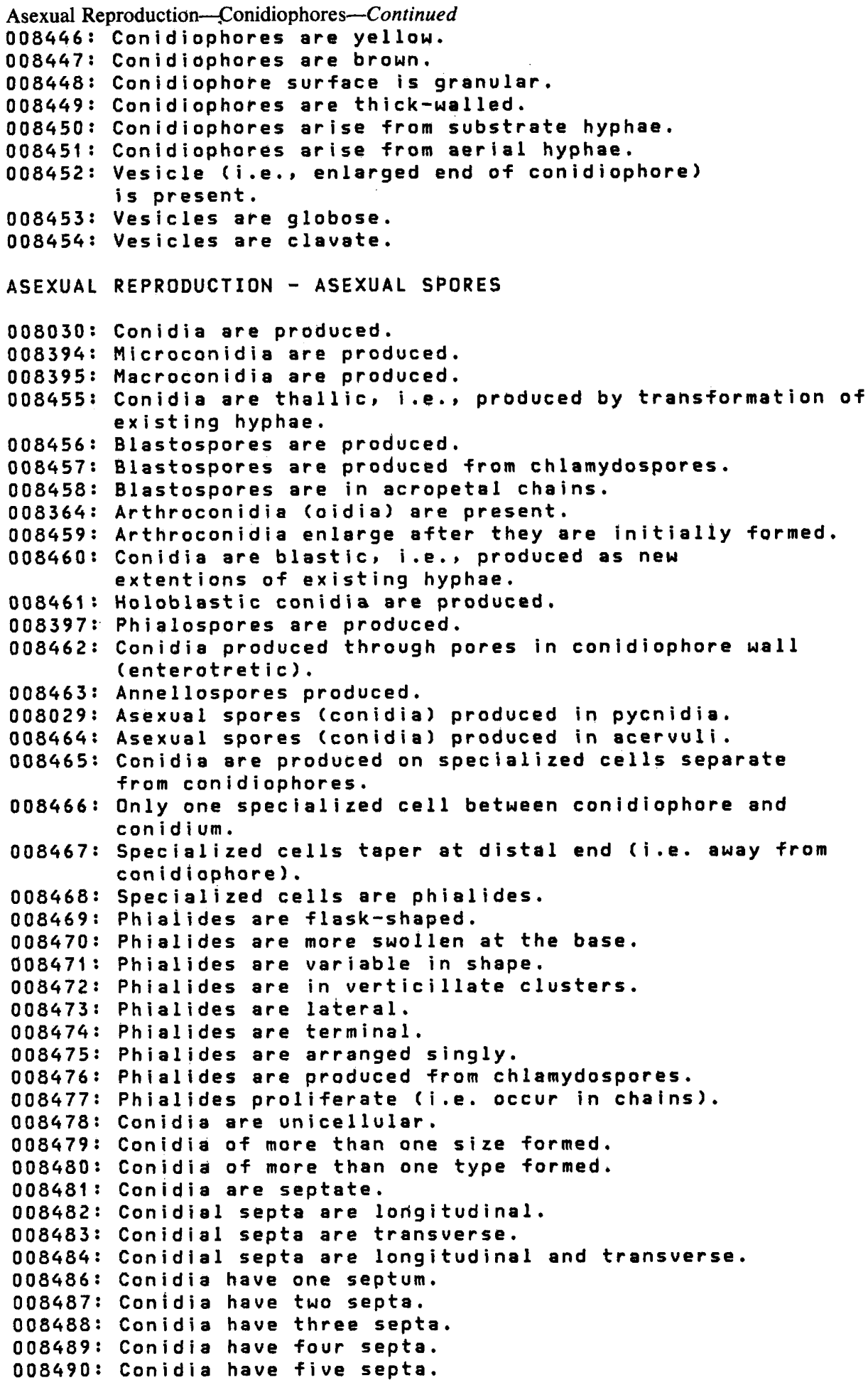


TABLE 1-Continued

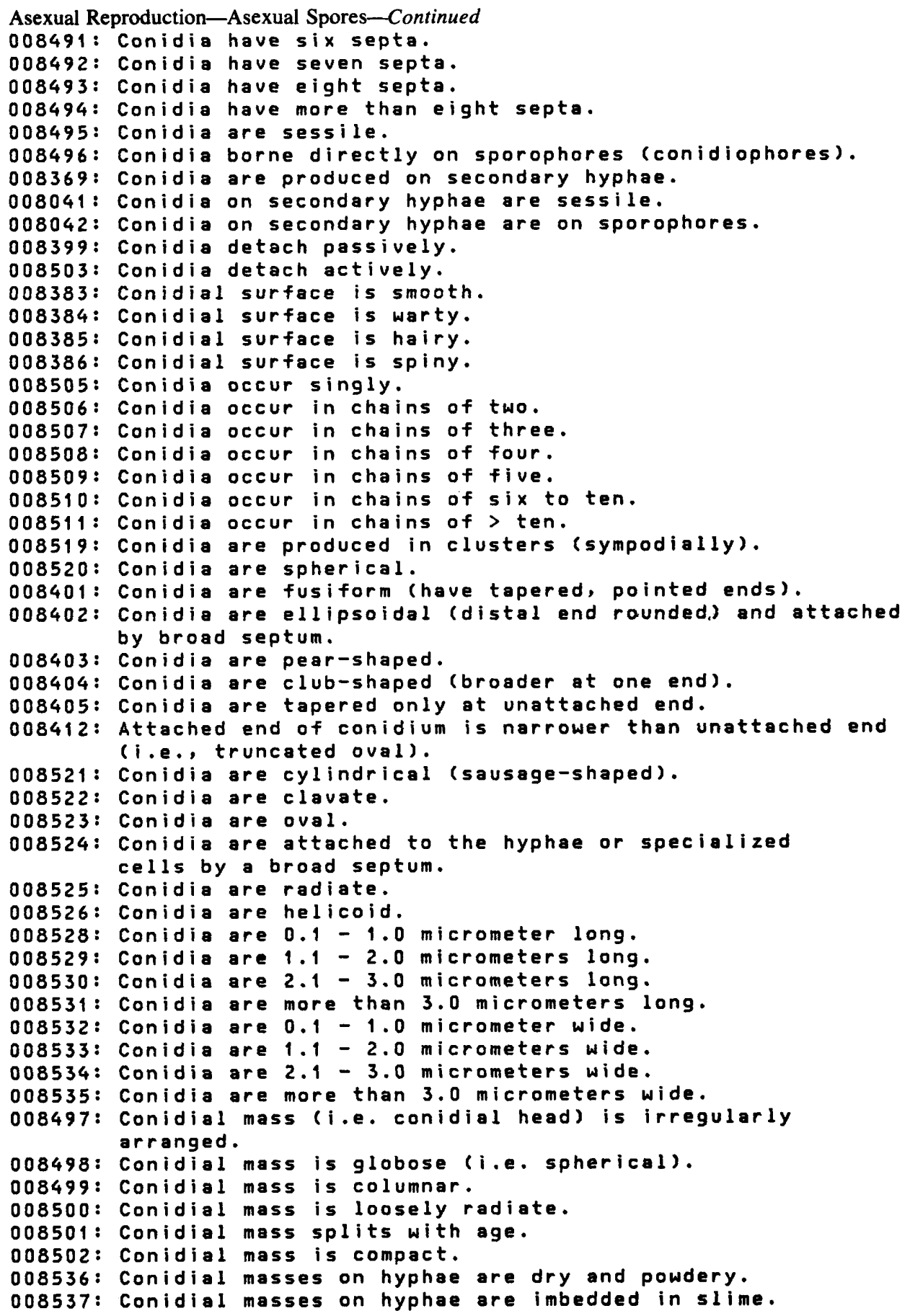

ASEXUAL REPRODUCTION - SPORANGIA

008173: Asexual spores are produced in sporangia (spore vesicles). 
TABLE 1-Continued

Asexual Reproduction-Sporangia-Continued

008538: Sporangia are sessile.

008539: Sporangia are on sporophores.

008194: The walls of sporangia are loose and clearly separated from the spores.

008195: The walls of sporangia form a tight sheath around the spores.

008196: Sporangiospores are released from a pore in the sporangial wall.

008197 : Sporangiospores are released through a rupture in the sporangial wa 11 .

008198: The sporangial wall disintegrates prior to the release of spores.

008199: The sporangial wall disintegrates concurrently with the release of spores.

008200: The sporangial wall remains after the release of spores.

008201 : Sporangia separate from the sporophore at the point of connection.

008202: Sporangia separate from the sporophore at a point below their connection.

008548: Collarette formed after release of sporangiospores.

008549 : Sporangia are apiculate.

008550: Sporangia are bell-shaped.

008551 : Sporangia are clavate.

008552 : Sporangia are cylindrical.

008553 : Sporangia are digital.

008554 : Sporangia are fusiform.

008555 : Sporangia are irregular.

008556: Sporangia are oval.

008557: Sporangia are pod-iike.

008558 : Sporangia are spherical.

008559 : Sporangia are urceolate.

008560: Sporangia are vermiforme.

008561: Columella is formed.

008562: Apophysis is present.

008563: Sporangial walls are smooth.

008564: Sporangial walls are spiny (echinulate).

008565 : Sporangial walls are warty (tubercular).

008566: Sporangia occur singly.

008567: Sporangia occur in clusters.

008568: Sporangia occur in rows.

008569: Sporangia are produced acropetally.

008570: Sporangia are produced laterally.

008571 : Sporangia are 1.0 - 2.0 micrometers long.

008572: Sporangia are 2.1 - 5.0 micrometers long.

008573 : Sporangia are 5.1 - 10.0 micrometers long.

008574: Sporangia are 10.1 - 15.0 micrometers long.

008575 : Sporangia are 15.1 - 20.0 micrometers long.

008576 : Sporangia are 21.0 - 30.0 micrometers long.

008577: Sporangia are 31.0 - 50.0 micrometers long.

008578 : Sporangia are 1.0 - 2.0 micrometers wide.

008579 : Sporangia are 2.1 - 3.0 micrometers wide.

008580: Sporangia are 3.1 - 4.0 micrometers wide.

008581 : Sporangia are 4.1 - 5.0 micrometers wide.

008582 : Sporangia are 5.1- $10.0 \mathrm{micrometers} w i d e$.

008583 : Sporangia are 10.1 - 15.0 micrometers wide.

008584 : Sporangia are 15.1 - 20.0 micrometers wide.

008585 : Sporangia are $21.0-30.0$ micrometers wide.

008273 : Sporangiospores are motile.

008274 : Sporangiospores have single polar flagella.

008275 : Sporangiospores have tufts of polar flagella.

008276 : Sporangiospores have lateral flagella.

008595: Sporangiospores are spherical.

008596: Sporangiospores are cylindrical. 
TABLE 1-Continued

\begin{abstract}
Asexual Reproduction-Sporangia-Continued
008597 : Sporangiospores are $0.1-1.0$ micrometer long.

008598: Sporangiospores are 1.1 - 2.0 micrometers long.

008599: Sporangiospores are 2.1 - $3.0 \mathrm{micrometers} \mathrm{long.}$

008600: Sporangiospores are 3.1 - 4.0 micrometers long.

008601: Sporangiospores are 4.1 - 5.0 micrometers long.

008602: Sporangiospores are $0.1-1.0$ micrometer wide.

008603 : Sporangiospores are 1.1 - 2.0 micrometers wide.

008604: Sporangiospores are 2.1 - 3.0 micrometers wide.

008605: Sporangioles are present.

008606: Sporangioles are spiny.
\end{abstract}

\title{
SEXUAL REPRODUCTION
}

008617: Sexual reproduction occurs.

008618: Organism is homothallic (male and female on same mycellium). NOTE: this is the same as code \#014006.

008619: Organism is heterothallic (male and female on separate mycelium exhibits interfertility). NOTE: this is the same as code \#014007.

014009: Interfertility is bi-polar.

014010: Interfertility is tetra-polar.

008620 : Gametangia are formed.

008621 : Gametangia are morphologically similar to vegetative

hyphae (i.e. no sexual differentiation).

008622 : Male gametangia are produced.

008623: Male gametes are produced.

008624: Conidia act as male gametes.

008625 : Female gametangia are produced.

008626: Female gametes are produced.

008627: Zygospores are produced.

008628: Zygospores are thick-walled.

008629: Zygospores are roughened.

008630: Zygospores are spiny.

008631: Only one supporting cell present.

008632: Two supporting cells present.

008633: Hyphae developed on supporting cells.

007071: Fruiting bodies are present.

007061: Fruiting bodies are butyrols.

007062: Fruiting bodies are deliquescent.

007063: Fruiting bodies are mucoid.

007064: Fruiting bodies are cartilagenous.

007065: Fruiting bodies are red.

007066: Fruiting bodies are orange.

007067: Fruiting bodies are yellow.

007068: Fruiting bodies are brown.

007069: Fruiting bodies are pink.

007070: Fruiting bodies are some color other than above.

008315: Cells in a multilocular structure cresulting from transverse and longitudinal septation) produce zoospores.

008607: Zoospores are spherical.

008608: Zoospores are cylindrical.

008609 : Zoospores are 0.1 - 1.0 micrometer long.

008610: Zoospores are 1.t - 2.0 micrometers long.

008611: Zoospores are 2.1 - 3.0 micrometers long.

008612 : Zoospores are $3.1-4.0 \mathrm{micrometers}$ long.

008613 : Zoospores are 4.1 - 5.0 micrometers long.

008614: Zoospores are 0.1 - 1.0 micrometer wide.

008615: Zoospores are 1.1 - 2.0 micrometers wide.

008616: Zoospores are 2.1 - 3.0 micrometers wide.

008634 : Asci are produced. 
Sexual Reproduction-Continued

008635: Ascus is cylindrical.

008636: Ascus is round.

008637: Ascus is in locule.

008638: Ascospores are oval.

008639: Ascospores are round.

008640: Four ascospores produced.

008641: Eight ascospores produced.

008642 : Paraphyses produced.

008643: Ascus is phototrophic.

008644: Ascus tip is phototrophic.

008645: Paraphyses are phototrophic.

008646: Fruit body is phototrophic.

008647: Asci develop in perithecium.

008648: Asci develop in apothecium.

008649: Asci develop in cleistothecium.

008650: Cleistothecial wall is entire.

008651: Cleistothecial wall is composed of peridial hyphae.

008652: Peridial hyphae are dumbbell-shaped.

008653 : Peridial hyphae are irregular on one side only.

007075: Only peridial hyphae are produced.

008654: Fruit body in stroma.

007073: Basidiospores are present.

008655: Teleospores formed.

008656 : Probasidium formed.

008657 : Probasidium septate.

008658: Sporidia formed.

008659 : Sporidia lateral.

008660: Sporidia terminal.

008661: Sporidia bud.

008398: Ballistospores are produced (also see section 7).

\section{MOTILITY OF CELLS}

013001: Cel1s motile.

013002 : Cells motile by flagella.

013009 : Cells have flagella.

013010: Flagellation polar.

013011: A single flagellum at one pole.

013012 : A single flagellum at both poles.

013013: Several flagella at one pole.

013014 : Several flagella at both poles.

013015 : Flagellation sub-polar.

013016 : A single flagellum near the pole.

013017 : Several flagella near the pole.

013018 : Flagella inserted frankly laterally (from the middle of the cel1).

013019: A single lateral flagellum.

013020 : Several lateral flagella.

013021: Flagella attached to the concave curve of the cell.

013022: Cells are peritrichous.

013023: Two or more flagella of distinctly different appearance in different locations on the cell.

013024 : Average wavelength of flagella is < 1.0 micrometer.

013025 : Average wavelength of flagella is $1.00-1.49$ micrometers.

013026 : Average wavelength of flagella is 1.50 - 1.99 micrometers.

013027 : Average wavelength of flagella is $2.00-2.49$ micrometers.

013028 : Average wavelength of flagella is $2.50-2.99$ micrometers.

013029: Average wavelength of flagella is $3.00-3.49$ micrometers.

013030 : Average wavelength of flagella is $3.50-4.00 \mathrm{micrometers}$. 
TABLE 1-Continued

Motility of Cells-Continued

013031 : Average wavelength of flagella is $>4.0$ micrometers.

013032 : Average amplitude of flagella is < $0.30 \mathrm{micrometer}$.

013033 : Average amplitude of flagella is 0.30 - $0.39 \mathrm{micrometer}$.

013034 : Average amplitude of flagella is 0.40 - 0.49 micrometer.

013035 : Average amplitude of flagella is $0.50-0.59 \mathrm{micrometer}$.

013036: Average amplitude of flagella is 0.60 - $0.70 \mathrm{micrometer.}$

013037 : Average amplitude of flagella is $<0.70$ micrometer.

\section{COLONY GROWTH AND APPEARANCE}

016292: Growth from inoculum covers plate within 1 week.

016293: Growth from inoculum covers plate within 2 weeks.

016294: Growth from inoculum covers plate within 3 weeks.

016295: Growth from inoculum covers plate within 4 weeks.

016296: Growth from inoculum covers plate within 5 weeks.

016297: Growth from inoculum covers plate within 6 weeks.

016298: Growth from inoculum covers plate within 7 or more weeks.

016008: Agar macro-colony margin is entire.

016009: Agar macro-colony margin is erose.

016010: Agar macro-colony margin is filamentous (rhizoid).

016011: Agar macro-colony margin is irregular.

016012: Agar macro-colony margin is undulate or lobate.

016361: Agar macro-colony margin is lobate.

016362: Agar macro-colony margin is undulate.

016189 : Agar macro-colony is convex.

016013: Agar macro-colony is low convex.

016014: Agar macro-colony is high convex.

016015: Agar macro-colony is convoluted.

016016: Agar macro-colony is flat (membranous).

016017 : Agar macro-colony is raised but not convex.

016188 : Edges of macro-colony raised higher than center (crater-shape).

016018: Agar macro-colony is umbonate.

016027: Colony surface is glistening.

016028: Colony surface is dull (matte).

016029: Colony surface is powdery, dry.

016030: Colony surface is smooth.

016031: Colony surface is rough.

\section{PIGMENTATION}

020001: Colonies are pure (paper) white on solid medium:

020002: Colonies are gray on solid medium.

020009: Underside of colony pigmented.

020066: Underside of colony is blue.

020067 : Underside of colony is yellow (golden).

020068: Underside of colony is green.

020069: Underside of colony is red.

020070: Underside of colony is orange.

020071: Underside of colony is violet (purple).

020072: Underside of colony is brown.

020073 : Underside of colony is black.

020074: Pigment on underside of colony is pH sensitive.

020019: Diffusible (water-soluble) pigments are produced.

020020: Diffusible blue pigments are produced.

020021 : Diffusible yellow pigments are produced.

020022: Diffusible green pigments are produced.

020023: Diffusible red pigments are produced.

020024: Diffusible orange pigments are produced.

020025 : Diffusible violet (purple) pigments are produced.

020081 : Non-diffusible pigment occurs in concentric rings within the 
TABLE 1-Continued

Pigmentation-Continued colony.

020056: Spores on surface of colony are pigmented (non-diffusible).

020038: Non-diffusible red pigments are produced.

020039: Non-diffusible brown pigments are produced.

020040: Non-diffusible green pigments are produced.

020041: Non-diffusible violet (purple) pigments are produced.

020042 : Non-diffusible blue pigments are produced.

020043: Non-diffusible golden (yellow) pigments are produced.

020044: Non-diffusible orange pigments are produced.

008433 : Hyphae are pigmented.

008434 : Hyphae change color with age.

$008435:$ Hyphae darken with age.

008436: Hyphae are black.

008437: Hyphae are red.

008438: Hyphae are yellow.

008439 : Hyphae are green.

008440: Hyphae are gray.

008409: Hyphae are brown.

\section{SYMBIOSIS}

016149: Organisms grow in symbiosis.

016154 : Cells grow in symbiosis with leguminous plants.

016155: Cells which grow in symbiosis with leguminous plants produce root nodules.

016156: Cells which grow in symbiosis with leguminous plants produce leaf nodules.

016157: Cells grow in symbiosis with non-leguminous plants.

016158: Cells which grow in symbiosis with non-leguminous plants produce root nodules.

016159: Cells which grow in symbiosis with non-leguminous plants produce leaf nodules.

016160: Organisms grow in symbiosis with invertebrate animals.

GROWTH CONDITIONS - PH

016194: Growth takes place at an initial pH of 10.0.

016165: Growth takes place at an initial pH of 9.6.

016053: Growth takes place at an initial pH of 9.0.

016352: Growth takes place at an initial pH of 8.5.

016187: Growth takes place at an initial pH of 8.0.

016377 : Growth takes place at an injtial pH of 7.5.

016054: Growth takes place at an initial pH of 7.0.

016376: Growth takes place at an initial pH of 6.5.

016055: Growth takes place at an initial pH of 6.0.

016288: Growth takes place at an initial pH of 5.7.

016193: Growth takes place at an initial pH of 5.5.

016056: Growth takes place at an initial pH of 5.0.

016375: Growth takes place at an initial pH of 4.8.

016172: Growth takes place at an initial pH of 4.5.

016057: Growth takes place at an initial pH of 4.0.

016058: Growth takes place at an initial pH of 3.5 .

GROWTH CONDITIONS - TEMPERATURE

017001: Optimum temperature 0-10 C.

017002: Optimum temperature 11-20 C.

017003: Optimum temperature 21-30 C.

017004: Optimum temperature 31-40 C.

017005: Optimum temperature 41-50 C. 
TABLE 1-Continued

Growth Conditions-Temperature-Continued

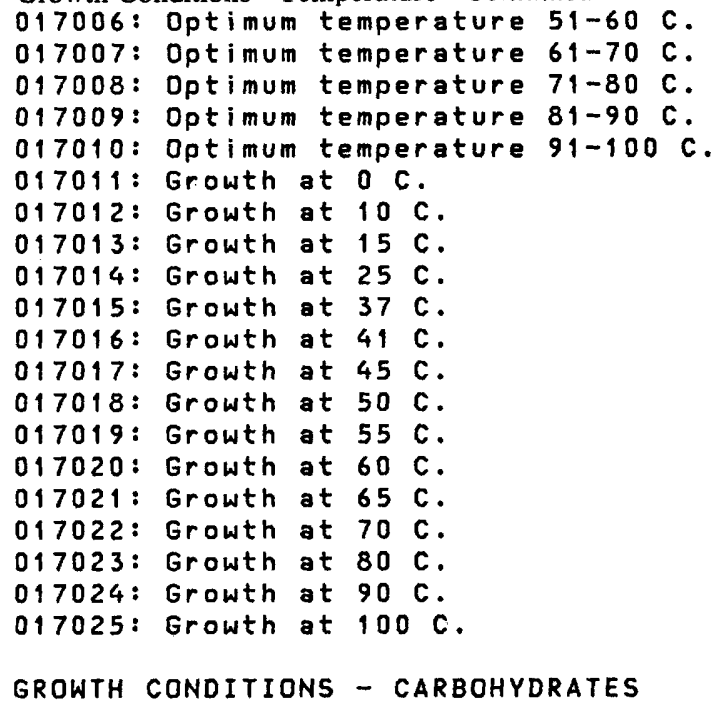


TABLE 1-Continued

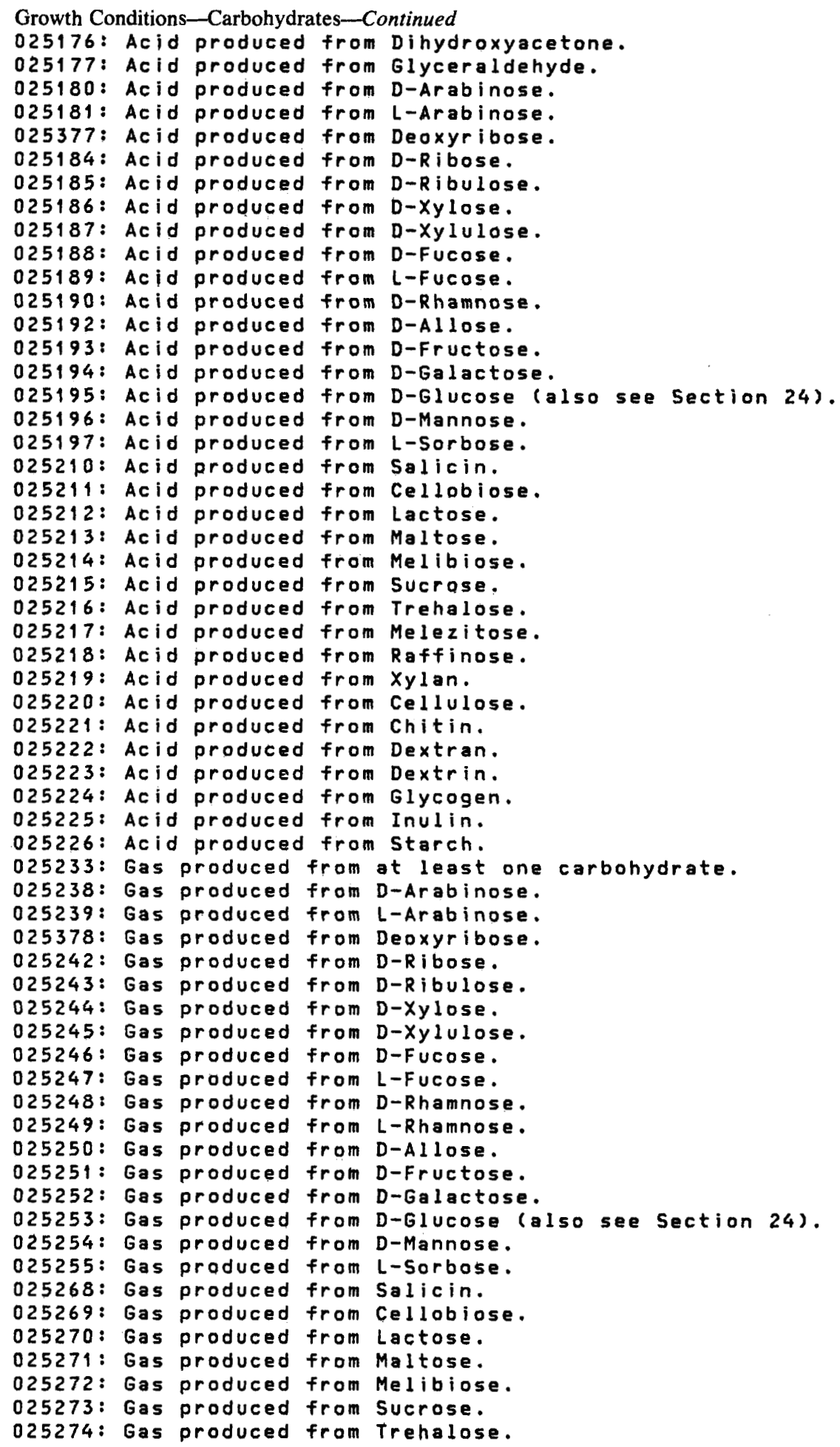


TABLE 1-Continued

Growth Conditions-Carbohydrates-Continued

025275: Gas produced from Melezitose.

025276: Gas produced from Raffinose.

025277: Gas produced from Xylan.

025278: Gas produced from Cellulose.

025279: Gas produced from Chitin.

025280: Gas produced from Dextran.

025281: Gas produced from Dextrin.

025282 : Gas produced from Glycogen.

025283 : Gas produced from Inulin.

025284 : Gas produced from Starch.

025291: At least one carbohydrate can be used as sole source of carbon.

025296: D-Arabinose can be used as the sole source of carbon.

025297: L-Arabinose can be used as the sole source of carbon.

025300: D-Ribose can be used as the sole source of carbon.

025301 : D-Ribulose can be used as the sole source of carbon.

025302: D-Xylose can be used as the sole source of carbon.

025303: D-xylulose can be used as the sole source of carbon.

025304: D-Fucose can be used as the sole source of carbon.

025305: L-Fucose can be used as the sole source of carbon.

025306: D-Rhamnose can be used as the sole source of carbon.

025307: L-Rhamnose can be used as the sole source of carbon.

025308: D-Allose can be used as the sole source of carbon.

025309: D-Fructose can be used as the sole source of carbon.

025310: D-Galactose can be used as the sole source of carbon.

025311: D-Glucose can be used as the sole source of carbon (also see Section 24).

025312: D-Mannose can be used as the sole source of carbon.

025313: L-Sorbose can be used as the sole source of carbon.

025327: Cellobiose can be used as the sole source of carbon.

025328: Lactose can be used as the sole source of carbon.

025329 : Maltose can be used as the sole source of carbon.

025330: Melibiose can be used as the sole source of carbon.

025331: Sucrose can be used as the sole source of carbon.

025332: Trehalose can be used as the sole source of carbon.

025333: Melezitose can be used as the sole source of carbon.

025334: Raffinose can be used as the sole source of carbon.

025335: Xylan can be used as the sole source of carbon.

025336: Cellulose can be used as the sole source of carbon.

025337: Chitin can be used as the sole source of carbon.

025338: Dextran can be used as the sole source of carbon.

025339: Dextrin can be used as the sole source of carbon.

025340: Glycogen can be used as the sole source of carbon.

025341: Inulin can be used as the sole source of carbon.

025342: Starch can be used as the sole source of carbon.

\section{GROWTH CONDITIONS - MISCELLANEOUS}

024010: Keratin is degraded.

016110: Niacin (nicotinic acid) is required for growth.

$016114:$ Thiamine is required for growth.

016132 : Synthetic mineral salts media will support growth in the absence of vitamins (growth factors) and organic nitrogen compounds, provided other sources of carbon, nitrogen, and energy are supplied.

016133: Synthetic mineral salts media will support growth in the absence of organic nitrogen compounds, provided other sources of carbon, nitrogen, energy, and vitamins (growth factors) are supplied.

016137: Ammonium salts can serve as the sole source of nitrogen for growth.

016138: Nitrate can serve as the sole source of nitrogen for growth.

034143 : Urease $(3.5 .1 .5)$ is produced. 
described, by Rogosa et al. (10); copies may be obtained from these authors.

\section{RESULTS AND DISCUSSION}

In previous preliminary studies and also in the present study, relevant general bacterial features and other features especially descriptive of actinomycetes and related organisms were extracted from the RKC Code list and included as such or used as models for new items. This list of features (Table 1), especially applicable to dermatophytes, aspergilli, phycomycetes, and certain darkly pigmented species of Phialosphora, Exophiala, Wangiella, and Cladosporium, is organized into 11 sections covering cell and colony morphology, cell size, nature of the cell wall, hyphal branching, septation and differentiation, reproduction, motility of cells, growth conditions, pigmentation, symbiosis, and physiology. It is not exhaustive, but it is intended to be a framework for studies similar to that on dermatophytes.

In the RKC Code, no distinction is made among features being coded according to biological type of organism. The features in Table 1 were not designed specifically for fungi; they were often taken directly from the RKC Code. Because microorganisms share many characteristics, only a few of the large number of available features are listed. Code subsets have been developed for protozoa (3) and for algae (unpublished data). That is, even if the wording of a feature description (e.g., "Mycelial growth occurs") applies equally well to bacteria and fungi, the feature still is assigned only one six-digit number (008336). The fact that the code number is being used to characterize a fungal or a bacterial strain is noted elsewhere in the data set. The list of features and their code numbers presented herein have been extracted from the master RKC code. It is that set which we believe is most likely to be of interest and use to mycologists. It should be noted that this list is not restrictive. Any of the code numbers (hence feature descriptions) already in the RKC code may be used. For example, items on nitrogen metabolism are extensively listed in the $\mathrm{RKC}$
Code and, if required, may be extracted as a subset from this document.

Features not in the RKC code may be added at any time by correspondence with the authors of this communication. Upon publication of this subset of the RKC code, it will be part of the general coding system which is maintained as the coding system of the World Federation of Culture Collections. Thus, we shall have a uniform method for coding and exchanging phenotypic information describing microbiological strains on a world-wide basis.

\section{ACKNOWLEDGMENTS}

We acknowledge valuable contributions from F. A. Benedict, H. Furuya, S. Jong, and D. King.

\section{REPRINT REQUESTS}

Address reprint requests to: Dr. Morrison Rogosa, Microbial Systematics Section, National Institute of Dental Research, Bethesda, MD 20205.

\section{LITERATURE CITED}

1. Benedict, F. A. 1979. Coding and entry of data. FDA ByLines 9:223-231.

2. Campbell, I. 1975. Numerical analysis and computerized identification of the yeast genera Candida and Torulopsis. J. Gen. Microbiol. 90:125-132.

3. Daggett, P. M., M. I. Krichevsky, M. Rogosa, J. O. Corliss, and J. P. Girolami. 1980. Method for coding data on protozoan strains for computers. J. Protozool. 27:353361.

4. Kendrick, W. B., and L. K. Weresub. 1966. Attempting neo-Adansonian computer taxonomy at the ordinary level in the basidiomycetes. Syst. Zool. 15:307-329.

5. King, D. S. 1976. Systematics of Conidiobolus (Entomophthorales) using numerical taxonomy. I. Biology and cluster analysis. Can. J. Bot. 54:45-65.

6. King, D. S. 1976. Systematics of Conidiobolus (Entomophthorales) using numerical taxonomy. II. Taxonomic considerations. Can. J. Bot. 54:1285-1296.

7. Kockova-Kratochvilova, A., E. Slavikova, and V. Jensen. 1978. Numerical taxonomy of the yeast genus Debaryomyces Lodder \& Kreger-van Rij. J. Gen. Microbiol. 104:257-268.

8. Krichevsky, M. I. 1979. The microbial information system (MICRO-IS): a system overview. FDA By-Lines 9:217222.

9. Philpot, C. M. 1977. The use of nutritional tests for the differentiation of dermatophytes. Sabouraudia 15:141150 .

10. Rogosa, M., M. I. Krichevsky, and R. R. Colwell. 1971. Method for coding data on microbial strains for computers (edition AB). Int. J. Syst. Bacteriol. 21:1 A-184A. 